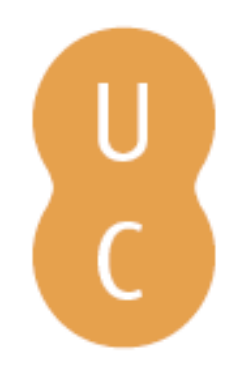

\title{
nombalina
}

\section{“O Estado Novo: como o devemos compreender": um debate radiofónico em 1937}

\author{
Autor(es): $\quad$ Cordeiro, Carlos
}

Publicado por: Imprensa da Universidade de Coimbra

URL

persistente: URI:http://hdl.handle.net/10316.2/32209

DOI: $\quad$ DOI:http://dx.doi.org/10.14195/978-989-26-0810-5_13

Accessed : $\quad$ 26-Apr-2023 15:49:27

A navegação consulta e descarregamento dos títulos inseridos nas Bibliotecas Digitais UC Digitalis, UC Pombalina e UC Impactum, pressupõem a aceitação plena e sem reservas dos Termos e Condições de Uso destas Bibliotecas Digitais, disponíveis em https://digitalis.uc.pt/pt-pt/termos.

Conforme exposto nos referidos Termos e Condições de Uso, o descarregamento de títulos de acesso restrito requer uma licença válida de autorização devendo o utilizador aceder ao(s) documento(s) a partir de um endereço de IP da instituição detentora da supramencionada licença.

Ao utilizador é apenas permitido o descarregamento para uso pessoal, pelo que o emprego do(s) título(s) descarregado(s) para outro fim, designadamente comercial, carece de autorização do respetivo autor ou editor da obra.

Na medida em que todas as obras da UC Digitalis se encontram protegidas pelo Código do Direito de Autor e Direitos Conexos e demais legislação aplicável, toda a cópia, parcial ou total, deste documento, nos casos em que é legalmente admitida, deverá conter ou fazer-se acompanhar por este aviso.

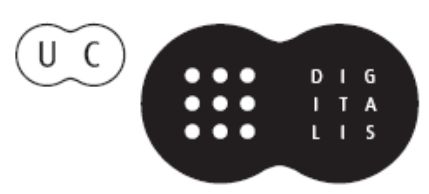




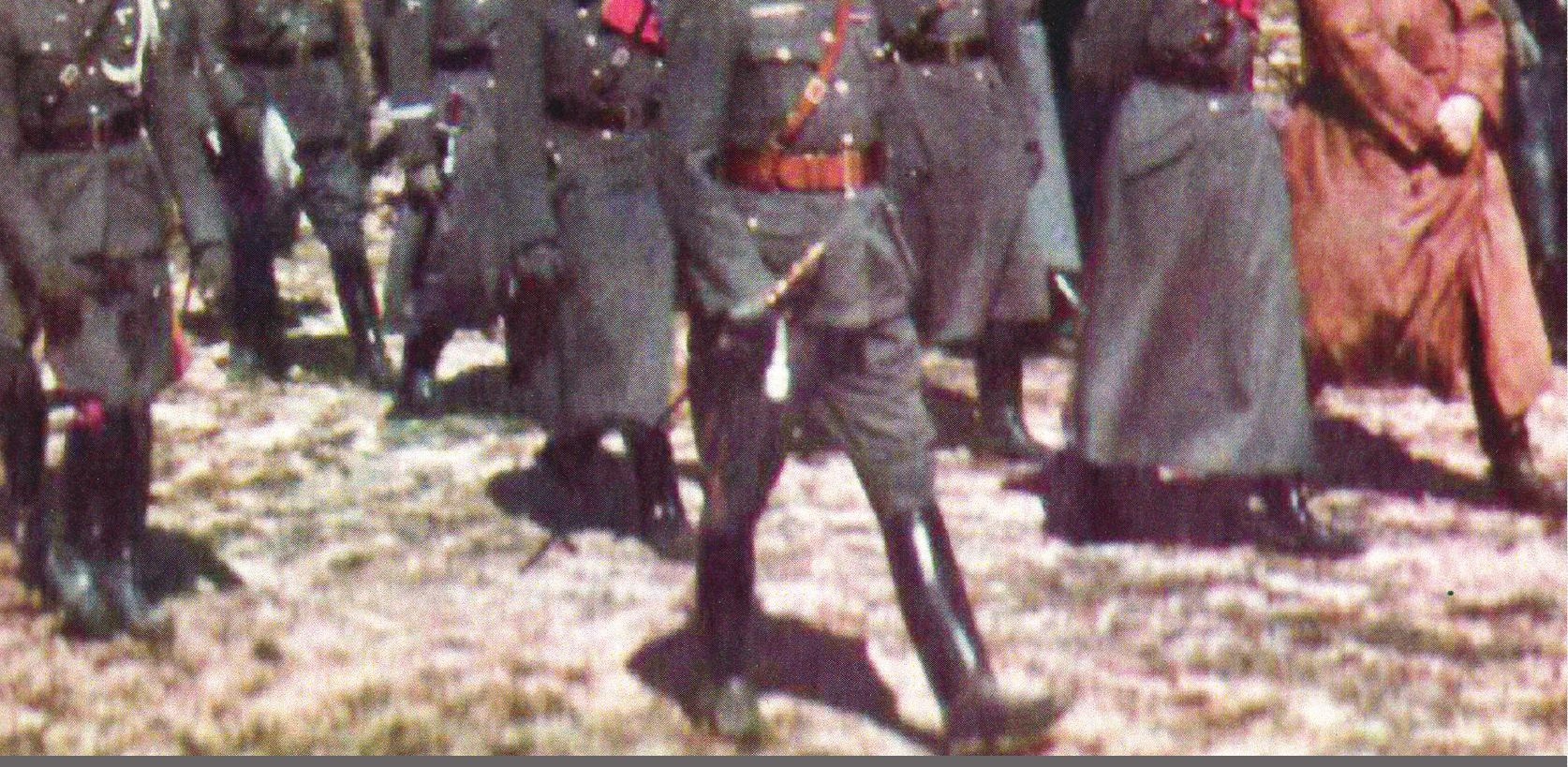

\section{Estados autoritários}

e totalitários

e suas representações

Coordenaação

Luís Reis Torgal

Heloísa Paulo

Coimbra · 2008

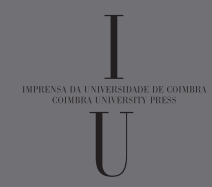




\section{Carlos Cordeiro}

\section{“O ESTADO NOVO - COMO O DEVEMOS COMPREENDER" UM DEBATE RADIOFÓNICO EM 1937}

O objecto da presente comunicação tem por base um debate político-ideológico que, no ano de 1937, se verificou na ilha de S. Miguel, suscitado por uma palestra radiofónica no pequeno posto emissor CT2AJ ${ }^{1}$ intitulada "O Estado Novo - como o devemos compreender”. Com regularidade, esta estação privada de radiodifusão emitia palestras sobre temas diversos, sobretudo ligados a questôes culturais, económicas, morais ou de propaganda do corporativismo, entre outras. Muitas dessas palestras eram, posteriormente, publicadas nos jornais locais, como, aliás, aconteceu com os textos em análise, que, depois de radiodifundidos e publicados na imprensa, foram também editados em opúsculos ${ }^{2}$.

Estamos conscientes de que se tratava de intervenções de elites para elites, como o provam alguns títulos que apresentamos: "Antero vivo: justificando uma opinião", de Oliveira San-Bento ${ }^{3}$; "Epopeias humanas e epopeias literárias", de Lúcio Agnelo Casimiro ${ }^{4}$; "Nala e Damaianti (episódio do Mahabahard)", de Lúcio de Miranda5; "Por Seara Alheia: resultados dos exames de admissão aos liceus em 1936. Projecto de reforma do ensino primário nacional", de António Augusto Riley da Motta ${ }^{6}$, ou, no campo da propaganda do Estado Novo, "A morte quer a democracia", de Armando Cândido ${ }^{7}$.

As repercussões públicas dessas palestras seriam, certamente, reduzidas, quer pelos temas abordados, quer pela fraca capacidade difusora da estação e certamente pelo

\footnotetext{
${ }^{1} \mathrm{O}$ posto emissor CT2AJ, de João Soares Júnior, iniciou as transmissões radiofónicas em 1931.

${ }^{2}$ Consultámos os quotidianos Diário dos Açores e Correio dos Açores, bem como o semanário Açoriano Oriental, todos de Ponta Delgada. Nos dois primeiros encontrámos a transcrição de diversas palestras nos números relativos ao primeiro semestre de 1937. O Açoriano Oriental não publicou, no mesmo período, qualquer palestra radiodifundida.

${ }_{3}$ Diário dos Açores, Ponta Delgada, 1937, Janeiro, 7. Esta intervenção enquadrava-se no vivo debate sobre características e localização do monumento a erigir a Antero de Quental.

${ }^{4}$ Cf. Correio dos Açores, Ponta Delgada, 1937, Janeiro, 26.

5 Cf. idem, 1937, Janeiro, 11.

${ }^{6}$ Cf. Idem, Ponta Delgada, 1937, Fevereiro, 26.

7 Cf. Idem, Ponta Delgada, 1937, Janeiro, 29.
} 
número reduzido de receptores que haveria, ainda que o Diário dos Açores publicasse regularmente a programação da CT2AJ e de estações estrangeiras como a Rádio Colonial Francesa e a BBC, entre outras ${ }^{8}$. Não será, porém, de excluir a hipótese de as palestras em análise terem alcançado maior atenção pública, quer pela notoriedade dos intervenientes, quer pelo tema em debate.

Com efeito, Francisco d'Athayde Machado de Faria e Maia, autor da palestra "O Estado Novo - como o devemos compreender" era bem conhecido pelos seus ideais republicanos e autonomistas. Terminado o curso de Direito, na Universidade de Coimbra (1901), regressou a Ponta Delgada, tendo desempenhado o cargo de inspector escolar, e leccionado no Liceu Antero de Quental. Viajou pela Europa, demorando-se na Suíça, País que tomou como referência em termos de organização política. Logo após a implantação da República, foi nomeado presidente da comissão administrativa da Câmara Municipal de Ponta Delgada e, em 1921, eleito senador, como independente, nas listas do Partido Regionalista ${ }^{9}$. Alguma expectativa lhe mereceu o movimento do " 28 de Maio", e, se bem que não tivesse militado na União Nacional e mantivesse algum distanciamento relativamente ao Estado Novo, ainda assim foi nomeado presidente da comissão administrativa da Câmara Municipal de Ponta Delgada, por duas vezes, a última das quais em 1940. De qualquer modo, não renunciaria aos ideais republicanos e autonomistas.

No lado oposto da "contenda" encontrava-se Armando Cândido de Medeiros, então delegado do Instituto Nacional do Trabalho e Previdência no distrito de Ponta Delgada $^{10}$, que, em 1920, pertencera ao núcleo integralista do Liceu Antero de Quental ${ }^{11}$ e, em 1927, publicara o livro Coimbra do meu Tempo, muito marcado pela ideologia integralista, destacando-se as citações de António Sardinha ${ }^{12}$. Foi presidente da Junta Geral do distrito de Ponta Delgada, deputado à Assembleia Nacional entre a quarta e a nona legislaturas e desempenhou cargos importantes na estrutura central da União Nacional.

${ }^{8}$ Cf., por exemplo, Diário dos Açores, Ponta Delgada, 1937, Janeiro, 15.

9 Cf. Carlos Cordeiro, Nacionalismo, Regionalismo e Autoritarismo nos Açores durante a I República, Lisboa, Salamandra, 1999, p. 331. A lista dos regionalistas incluía um candidato monárquico, pelo que Faria e Maia se sentiu na obrigação de reafirmar os seus ideais republicanos: "sou republicano, como sou livre-pensador, sem odiar os padres, nem a religião, só condenando os fanáticos e os hipócritas; sou republicano, como sou aristocrata, orgulhando-me de ter na minha ascendência uma longa série de homens de bem, mas não deixando, por isso de ter mais alta consideração e respeito pelo homem de ascendência humilde, nobre e honesto do que pelo duque ou príncipe, com uma longa ascendência de predomínio e riqueza, mas ser inútil, sem outros títulos nobiliárquicos do que o acaso do nascimento que inverte a única, a verdadeira ordem da nobreza, que é resultante da natureza e não das convençôes humanas. Eis como sou republicano". Francisco d'Athayde M. de Faria e Maia, Em Prol da Descentralização. "Livre administração dos Açores pelos Açorianos", 2. ${ }^{\text {a }}$ edição, Ponta Delgada, Jornal de Cultura, 1994, pp. 164-165. (1. a edição, 1932).

${ }^{10}$ V. Diário dos Açores, Ponta Delgada, 1937, Janeiro, 13.

${ }^{11}$ Em entrevista concedida a um quotidiano micaelense, na sequência da sua nomeação como delegado distrital do INTP, Armando Cândido defendia que a sua adesão ao corporativismo era já antiga, pois, em 16 de Novembro de 1920 (tinha então 16 anos e era estudante do Liceu de Ponta Delgada), no jornal A Monarquia, tinha declarado a sua adesão ao Integralismo Lusitano. Diário dos Açores, Ponta Delgada, 1937, Fevereiro, 3.

12 Cf. Carlos Cordeiro, ob.cit., pp.119-122. 
Como se referiu, a palestra que despoletou o debate político-ideológico foi proferida por Francisco d'Athayde Machado de Faria e Maia aos microfones do porto emissor CT2AJ, em Janeiro de 1937, tendo, posteriormente, sido transcrita na imprensa diária $^{13}$ e editada em opúsculo ${ }^{14}$. Segundo Faria e Maia, a palestra visava um objectivo principal: demonstrar, aos defensores dos princípios liberais, a compatibilidade das novas instituições com a manutenção da liberdade individual. Simultaneamente, criticava fortemente os propagandistas do novo regime, por desvirtuarem a essência das novas instituiçôes ao verberarem os princípios dos filósofos das Luzes e da Declaração dos Direitos do Homem e do Cidadão, de 1789, anatemizando a liberdade como se esta fosse incompatível com a autoridade e a ordem. Havia, pois, que clarificar as verdadeiras intençôes do Estado Novo, para desfazer equívocos, quer dos seus críticos, quer dos seus mais acérrimos defensores ${ }^{15}$.

Para fundamentar a essência liberal do Estado Novo, Faria e Maia recorre à Declaração dos Direitos do Homem e do Cidadão, procurando demonstrar que, afinal, os princípios da liberdade, da igualdade legal, da soberania nacional não eram postos em causa pela Constituição de 1933, contrariamente às invectivas de certos defensores da nova ordem, que lançavam suspeitas nos espíritos liberais de que se pretendia o regresso ao passado absolutista e, ao mesmo tempo, abrindo caminho aos "mal intencionados" que aproveitariam para propagar a ideia de que o governo pretendia anular as conquistas liberais tão penosamente alcançadas:

“Condenar aquele Código dos Direitos do Homem é condenar os próprios princípios em que se baseou o Estado Novo e em que não podia deixar de se basear, para não ser um anacronismo na vida social e mental da humanidade"16.

Ora, na sua leitura, o Estado Novo pretendia, no fundo, evitar a adulteração dos princípios fundamentais expressos na Declaração dos Direitos de $1789^{17}$. O Estado Novo não punha em causa os direitos individuais ao destacar os direitos colectivos, na medida em que, "se o Homem não se pode isolar da Humanidade", os direitos conferidos a cada indivíduo seriam mera "parcela do direito colectivo", não podendo, portanto, ser contrários à sociedade ${ }^{18}$.

A Democracia, entendida no sentido de soberania popular, não era negada pelo regime corporativo. E Faria e Maia continua:

"É servir mal o Estado Novo mostrá-lo sob um aspecto antagónico com os princípios que a Humanidade conquistou em séculos de laboriosa evolução mental e que anseia por ver concretizados inteiramente nas instituições, na alma e na mentalidade dos povos. É servir mal o Estado Novo dar-lhe aparência duma barreira contra as aspirações de maior justiça, de mais equidade, de maior equilíbrio económico entre os homens. É servir

\footnotetext{
13 Transcrita no Diário dos Açores, Ponta Delgada, 1937, Janeiro, 26.

${ }^{14}$ Francisco d'Athayde Machado de Faria e Maia, O Estado Novo - como o devemos compreender, Ponta Delgada, Of. do Diário dos Açores [1937].

${ }^{15}$ Cf. ibidem, pp. 4-5.

16 Ibidem, p. 6.

${ }^{17}$ Ibidem, p.8.

18 Ibidem, p. 6.
} 
mal o Estado Novo, fazê-lo revestir a forma dum baluarte de classes contra classes, de direitas contra esquerdas ${ }^{19}$ ".

Propagar, pois, a ideia de que era necessário extremar os campos político-ideológicos e apresentar a liberdade como antagónica da autoridade desvirtuava as verdadeiras matrizes do Estado Novo, que se pautavam pelo princípio da evolução contra a revolução, o que merece a total concordância de Faria e Maia. De facto, para Faria e Maia, Liberdade e Autoridade eram uma espécie de duas faces da mesma moeda: uma não destruía a outra. A Autoridade seria o fiscal da Liberdade, vigiando a sua conformação aos limites impostos pelo Direito: o respeito pela Liberdade dos outros ${ }^{20}$.

Faria e Maia não renega a sua admiração pelos "Filósofos das Luzes" ao afirmar a sua crença optimista na evolução da Humanidade para um "estado cada vez mais perfeito, cada vez de maior equilíbrio, de mais justiça e bem-estar" ${ }^{21}$ :

"A Humanidade progride, progride sempre; os princípios, as ideias libertadoras que se elaboram nas mentes superiores, marcando como fachos luminosos a via do Bem, não se têm perdido, não se extinguem; não podem ofuscar-se temporariamente; parecem, por vezes, abismar-se no pélago imenso do tempo, mas apenas se ocultam para reaparecer mais vigorosas, mais depuradas de erros que a ciência vai desfazendo, mais fortificadas pelo trabalho de gerações sucessivas" 22 .

Uma outra matriz da ideologia liberal - o individualismo - é também destacada nesta intervenção. A solidariedade social em que se fundamentava o Estado Novo, bem como a compreensão dos deveres sociais e a cooperação das classes na vida nacional tudo isto resultava das acções isoladas dos indivíduos ${ }^{23}$. Havia, nesta perspectiva, que insistir no investimento na instrução, motor essencial de progresso, contrariamente ao que defendiam as classes superiores que, no seu egoísmo, pretendiam evitar a evolução igualitária das classes. A falta de instrução seria, ao invés, propiciadora de convulsôes e anarquia ${ }^{24}$. Se, pois, o Estado Novo pretendesse acelerar a evolução, pela mudança das mentalidades, teria que apostar fortemente na instrução. Caso contrário, teria "vida fictícia, ou pelo menos limitada à vida política do seu iniciador" 25 .

Em suma: o Estado Novo é-nos apresentado como garante de liberdade pela autoridade; como defensor da igualdade perante a lei, mas respeitador das "desigualdades naturais"; como propugnador da soberania popular, considerada fonte da legitimidade do exercício do poder; como salvaguarda da ordem contra a desordem e da evolução - construtiva contra a revolução - destruidora.

Ora, é este modo de defender o Estado Novo, procurando destacar a sua fundamentação e procedimentos com base nos valores e princípios da democracia, com

\footnotetext{
${ }^{19}$ Ibidem, pp. 6-7.

20 Ibidem, p. 7.

${ }^{21}$ Ibidem, p. 10.

22 Ibidem, p. 11.

23 Cf. Ibidem, pp. 13-14.

${ }^{24}$ Cf. Ibidem, p. 12.

25 Cf. Ibidem, p. 13.
} 
críticas cerradas aos propagandistas do novo estado de coisas que, na opinião de Faria e Maia, alteravam por completo a essência das novas instituiçôes, que iria desencadear uma fortíssima reacção de um dos visados, mas não nomeados, nesta palestra.

Armando Cândido, empolgado pelo que considerava ser dever do cargo que desempenhava, o de delegado distrital do Instituto Nacional do Trabalho e Previdência, procura rebater, ponto por ponto, a argumentação de Francisco Faria e Maia, com abundantes citações do Decálogo do Estado Novo, dos discursos de Salazar, da Constituição de 1933, de ideólogos do Estado Novo e do pensamento contra-revolucionário (cita, por exemplo, Gama e Castro ${ }^{26}$ ). Assim, começa por contestar vivamente a possibilidade de conciliação da "liberal-democracia", com a doutrina estadonovista. Em primeiro lugar, a problemática da soberania popular, que Faria e Maia "descobria" no sistema corporativo da Constituição de 1933 , ao citar o $\operatorname{art}^{\circ}{ }^{\circ} 71 .^{\circ}$ - "a soberania reside na Nação". Armando Cândido, socorrendo-se do Decálogo do Estado Novo e de afirmações de Salazar não tem dúvidas em afirmar que a política estadonovista era o oposto da ideia de soberania "saída dos indivíduos soberanos e egoístas": a verdadeira representação nacional era constituída pelos "elementos reais e permanentes da vida nacional - famílias, municípios, associações, corporaçôes, etc" ${ }^{27}$. Assim, o Estado Novo só podia ser antidemoliberal, opondo à concepção da vontade geral como resultante da vontade da maioria, a da vontade da nação jurídica e unitária e não a soma dos indivíduos que votam num determinado momento. O parlamentarismo impedia a continuidade governativa uma vez que os indivíduos soberanos não cuidavam dos interesses nacionais mas dos das facções, quando não de um só ${ }^{28}$.

Um outro aspecto fortemente rebatido por Armando Cândido reporta-se à possibilidade de conciliação da liberdade com a autoridade, que Faria e Maia defendera. O Estado Novo, na perspectiva do delegado do Instituto Nacional do Trabalho e Previdência, invertera os termos: primeiro a autoridade; depois, não a Liberdade com "L" maiúsculo, mas as liberdades. Neste caso, socorre-se da autoridade do "Chefe", que, na famosa entrevista a António Ferro esclarecia: "autoridade e liberdade são dois conceitos incompatíveis... Onde existe uma não pode existir a outra [...]. Autoridade absoluta pode existir. Liberdade absoluta não existe nunca" ${ }^{29}$. E acrescentava: "A liberdade garantida pelo Estado, condicionada pela autoridade, é a única possível, aquela que pode conduzir, não digo à felicidade do homem, mas à felicidade dos homens ${ }^{30}$. Nesta interpretação, à liberdade "utópica e indefinida" substituíam-se as liberdades "concretas", que, segundo o Decálogo do Estado Novo, se definiam pela "faculdade de fazer ou deixar de fazer, de possuir ou deixar de possuir alguma coisa concreta" 31 . Contrariamente à doutrina liberal, em que a liberdade tinha por limite

\footnotetext{
26 Sobre o pensamento e acção de José da Gama e Castro (1795-1873), veja-se Luís Manuel Reis Torgal, Tradicionalismo e Contra-Revolução. O Pensamento e a Acção de José da Gama e Castro, Coimbra, Universidade de Coimbra, 1973.

${ }_{27}$ Armando Cândido, Teatro Anatómico. Dissecando uma Palestra, Ponta Delgada, [s. n.], 1937, p. 4.

28 Ibidem, p. 5.

${ }^{29}$ Ibidem, p. 10.

${ }^{30}$ Ibidem, pp. 10-11.

${ }^{31}$ Ibidem, p. 12.
} 
a liberdade dos outros, para o Estado Novo, o limite das liberdades seria o interesse nacional. Reforçando esta ideia da incompatibilidade da liberdade com a autoridade, Armando Cândido afirmava que a autoridade subjuga a liberdade, ou seja, para o Estado Novo, a autoridade não era mero fiscal da liberdade, como afirmava Faria e Maia: a "autoridade está em cima e a liberdade em baixo" 32 . Citava ainda Mussolini - "é preciso cada qual merecer a sua liberdade" e Gama e Castro - a liberdade como meio e não como fim ${ }^{33}$.

Relativamente à igualdade, e para que não restassem dúvidas sobre a inviabilidade da sua aplicação como um dos princípios estruturantes da organização social, define-a logo como "mito". Aliás, na sua perspectiva, a própria Declaração dos Direitos do Homem e do Cidadão, ao basear exclusivamente as desigualdades sociais na utilidade comum, era em si um contra-senso: utilidade comum significaria servir. Ora, como conceber o servir face aos "soberanos direitos do homem" 34 ? No fundo, a própria Constituição de 1933 definia claramente o significado da igualdade perante a lei (art. ${ }^{\circ}$ 5..$^{\circ}$, ao ressalvar "as diferenças resultantes da natureza" e as "impostas pela diversidade das circunstâncias ou pela natureza das coisas" 35 , além de que Salazar definira a nação como "um todo orgânico constituído por indivíduos diferenciados em virtude das aptidôes diferentes, hierarquizados na sua diferenciação natural”. Ora, como para o Estado Novo o indivíduo só existia enquanto integrado em "grupos naturais", era nessa qualidade que lhe eram reconhecidos "todos os necessários direitos", como se defendia no Decálogo do Estado Novo, ou seja, "os direitos concretos dos homens" e não os "direitos abstractos do Homem" 36.

Armando Cândido termina a sua palestra com ironia: O título da palestra de Faria e Maia estava errado. Em vez de O Estado Novo - como o devemos compreender, devia ter sido O Estado Novo - como o não devemos compreender ${ }^{37}$.

Estas duas intervenções radiodifundidas, publicadas em jornais e depois em opúsculos, deram lugar a mais duas palestras, sem que, no entanto, nada de substancial tivessem acrescentado às anteriores. Foram nulas as reacções da imprensa a esta polémica, além da transcrição das palestras.

Faria e Maia responderia prontamente ${ }^{38}$ à conferência de Armando Cândido, reafirmando, na oportunidade, a necessidade de a propaganda do Estado Novo enveredar pelo espírito conciliador, eliminando qualquer aparência de facciosismo, que, aliás, não se conformava com "serenidade fria e desapaixonada do Chefe" ${ }^{39}$. A substituição do

32 Ibidem, p. 12.

33 Ibidem, p. 13.

${ }^{34}$ Ibidem, p. 16.

35 Ibidem, p. 17.

36 Ibidem, p. 16.

37 Ibidem, p. 32.

${ }^{38}$ A conferência foi proferida aos microfones da CT2AJ em 6 de Fevereiro, publicada no Correio dos Açores, Ponta Delgada, 1937, Fevereiro, 11, e no opúsculo Francisco d'Athayde Machado de Faria e Maia, Contenda... em boa paz, Ponta Delgada, Of. do “Diário dos Açores”, 1937.

${ }^{39}$ Francisco d'Athayde Machado de Faria e Maia, Contenda..., p. 7. 
espírito de partido ou de facção - "uma das características mais vincadas na psicologia portuguesa" - por um "ideal nacional” que congregasse todos os portugueses, quaisquer que fossem os seus credos, havia sido um dos propósitos do Estado Novo que mais o cativara ${ }^{40}$. Mas, mantinha a expectativa na concretização destes propósitos, uma vez que a sua aplicação, como, aliás, vinha acontecendo por todo o lado com a doutrina liberal, podia vir a ser adulterada. $\mathrm{Na}$ sua perspectiva, era precisamente isto que se verificava com as interpretaçôes que alguns propagandistas, como Armando Narciso, vinham fazendo das novas instituições.

De resto, reforçava a sua leitura da Constituição de 1933, no respeitante à origem popular da soberania, citando o art. $^{\circ} 71 .^{\circ}$, e aos direitos e garantias individuais, $\left(\right.$ art. $^{\circ}$ $\left.8 .^{\circ}\right)$, nomeadamente quanto às liberdades. $\mathrm{O}$ facto de virem expressas as liberdades não era contraditório com o ideal de Liberdade provindo da Declaração dos Direitos, pois, na sua perspectiva, Liberdade pressupõe várias espécies de liberdades.

A resposta de Armando Cândido não traz também nada de novo. Continua a citar discursos de Salazar e de outros ideólogos do Estado Novo para ridicularizar, num estilo fortemente demagógico, a possibilidade de mistura democrática-liberal-Estado Novo ${ }^{41}$.

Nestas duas últimas palestras há, no entanto, um aspecto que surpreende, mas, sobretudo, na de Faria e Maia: a avaliação ideológica dos regimes da Itália fascista e da Alemanha nazi. Com efeito, já anteriormente, na palestra radiofónica $A$ morte quer a democracia ${ }^{42}$, Armando Cândido tinha exaltado estes dois regimes e o do Japão. No caso italiano, destacava-se a confiança no "chefe", que construíra a unidade ideológica e dela resultara a unidade guerreira do povo. No caso da Alemanha, destaca-se a obediência e sujeição do povo a Hitler, que renovara o país sem parlamentos "a arder nas palavras", construindo, enquanto os inimigos discutiam, mostrando "a razão apoiada nas armas", enquanto os outros opunham "a teoria apoiada na lógica":

"Governo forte, direcção única, pensamento indivisível, o Estado alemão alargou as asas, rompeu para cima, e, de concessão em concessão, pelos degraus dos factos consumados, dá guinadas por aí fora" ${ }^{43} \ldots$

Quanto ao Japão, novamente o destaque para o espírito de unidade e a rejeição dos ideais demoliberais, que conduziriam, certamente, o Japão até às portas da Rússia.

A posição de Faria e Maia sobre a implantação dos regimes fascista e nazi demonstra uma interpretação da democracia, no mínimo, demasiado elástica. Com efeito, já tinha afirmado que por democracia entendia a influência do povo na governação pública e daí considerar que o Estado Novo não se afastava, nesta perspectiva, da Declaração dos Direitos, de $1789^{44}$. Mas agora irá ainda mais longe, integrando os regimes de Mussolini e de Hitler na sua perspectiva de soberania popular. Afinal, as "maiores revoluções democráticas” que a história registava só foram possíveis porque a força de Mussolini

40 Ibidem, p. 8.

${ }^{41}$ Armando Narciso, ob. cit., p. 36. A palestra foi publicada no Correio dos Açores, Ponta Delgada, 1937, Fevereiro, 13 e incluída no opúsculo Teatro Anatómico...

42 Transcrita no Correio dos Açores, Ponta Delgada, 1937, Janeiro, 20.

43 "A morte quer a democracia", Correio dos Açores, Ponta Delgada, 1937, Janeiro, 20.

${ }^{44}$ Francisco d'Athayde Machado de Faria e Maia, Estado Novo..., p. 8. 
e de Hitler provinha das aspirações populares. Mussolini, oriundo da classe operária, marchara sobre Roma à frente milhares de homens, tal como ele, das classes operárias e, impondo-se ao rei, realizou "a maior reforma social que os mais avançados democratas nunca pensaram realizar incruentamente”. Hitler, levado ao poder pela força do voto, declarara que tinha realizado "a mais avançada obra democrática da Europa". Seriam, perguntava Faria e Maia, “condenáveis estes expoentes máximos da soberania popular” ${ }^{45}$ ? Talvez o fossem os processos impositivos de que se tinham servido, por vezes, mas isto era desculpável, pois resultava das necessidades transitórias das ditaduras.

Armando Cândido terá ficado surpreendido com estas posiçôes de Faria e Maia. Seria fácil refutar estas interpretações liberais do fascismo e do nazismo.

Desde logo o carácter da marcha sobre Roma. Não se tratara de uma marcha do povo como amálgama de indivíduos separados por interesses, graus de consciência, crenças e sentimentos diversificados, mas de "uma massa disciplinada, doutrinada [...] uniformizada com a camisa negra do querer consciente", não havia, pois, qualquer confusão possível entre o povo, no sentido liberal, a soma dos indivíduos soberanos, e a marcha de Mussolini sobre Roma. Relativamente às afirmações de Hitler de que tinha realizado a "mais avançada obra democrática da Europa", havia que ter em atenção que ele também havia dito: "se a democracia ainda pode ter um bom sentido, a Alemanha realiza a verdadeira Democracia" ${ }^{4}$.

A apresentação sucinta do debate radiodifundido e divulgado também nos jornais e editado em opúsculos terá interesse, não só pelo tema ou temas em discussão, mas também por outro tipo de questôes.

Em primeiro lugar, pela relevância social e política dos dois intervenientes. Temos, por um lado, um velho republicano independente, que desempenhara funções oficiais, ainda na Monarquia, mas também na República e já no tempo da Ditadura Militar (presidente da Comissão Administrativa da Câmara Municipal de Ponta Delgada, em 1932) e, depois, no Estado Novo (presidente da Comissão Administrativa da Câmara Municipal de Ponta Delgada entre 1940 e 1943). A colaboração com a Ditadura Militar não seria, porém, muito auspiciosa. $\mathrm{Na}$ proposta de aproveitamento turístico de S. Miguel, elaborada por uma comissão nomeada pelo ministério do Interior, de que era relator, Faria e Maia recorria ao discurso autonomista de afrontamento radical, salientando a justiça das reivindicações distritais relativamente ao aumento das receitas das juntas gerais: "somente queríamos que o Estado nos deixasse na posse [...] pelo menos do que for suficiente para realizarmos a obra de fomento mais capital para o nosso futuro económico, sem que estejamos sempre a importuná-los, vexando-nos com pedidos e solicitaçôes que nos cansam, nos humilham e... nos revoltam”. Terá sido este tipo de discurso radical o ponto de partida para a mobilização das "forças vivas" de S. Miguel na reclamação de mais autonomia política e financeira e que conduziria à realização de greves e manifestações populares, uma das quais resultou em dois mortos e vários feridos ${ }^{47}$. E se o jornal de cariz democrático e maçónico $A$ Gazeta

${ }^{45}$ Idem, Contenda..., p. 9.

${ }^{46}$ Armando Narciso, ob. cit., p. 51.

${ }^{47}$ Cf. Carlos Cordeiro, Nacionalismo, Regionalismo e Autoritarismo nos Açores durante a I República, Lisboa, Salamandra, 1999, p. 426. V., também, Carlos Enes, "Ponta Delgada: o movimento de contestação 
rejubilara com a nomeação, nesse ano de 1932, de Faria e Maia para presidente da Comissão Administrativa da Câmara Municipal de Ponta Delgada, relembrando o seu desempenho do mesmo cargo logo a seguir à implantação da República e até 1913 (o que o nomeado, aliás, não deixaria de lembrar no seu discurso de posse) ${ }^{48}$, o certo é que foi efémera essa sua nova passagem pela presidência da Câmara Municipal de Ponta Delgada, pois, ainda nesse ano, seria substituído por um oficial do Exército.

No lado oposto, um antigo integralista, que merecera a confiança do regime para enveredar pelos caminhos da política activa, primeiro como delegado do Instituto Nacional do Trabalho e Previdência e depois, além do desempenho de cargos administrativos distritais, o assento na Assembleia Nacional em seis legislaturas, e a ocupação de postos directivos na estrutura central da União Nacional.

Faria e Maia acolhera positivamente a Ditadura Militar e, depois, o Estado Novo, mas procurava, por outro lado, não renegar as suas origens ideológicas marcadamente liberais. O próprio projecto de Constituição, quando foi lançado a debate, não lhe mereceu especiais reparos, excepto quanto à demasiada centralização, a que contrapunha a transformação do País em estado federal ${ }^{49}$. Considerava que o projecto revelava "propósitos honestos de bem servir a Nação, procurando subtraí-la ao estado anárquico social e de instabilidade governamental" que determinara e justificara o movimento de 28 de Maio de $1926^{50}$. As suas palestras vêm clarificar a interpretação que dava às novas instituições. No fundo, a sua "leitura" do Estado Novo não parece ingénua. Convencido de que os valores da Declaração dos Direitos do Homem e do Cidadão constituíam uma das mais importantes conquistas da Humanidade, não deixava, porém, de reconhecer que, na prática política, esse guião por que se devia pautar a vida das sociedades e a actuação dos governos tinha sido adulterado para o serviço de facções que olhavam aos seus interesses ao invés de cuidarem dos interesses nacionais. Salazar, "o chefe", parecia querer terminar com a "anarquia" que vigorara em Portugal.

E é neste dilema que vive Faria e Maia: por um lado, a fidelidade aos valores; por outro, a "simpatia" por um sistema político posto em causa pelos seus antigos companheiros de caminhada ideológica. Havia, pois, primeiro, que se auto-convencer do respeito do Estado Novo pelos princípios fundamentais característicos dos regimes liberais: liberdade, igualdade legal, tolerância, soberania popular; depois, fazer passar esta mensagem para convencer os hesitantes.

Mas isto exigia a contenção da propaganda extremista em que se afadigavam os principais defensores locais do Estado Novo, de modo a congregar em vez de afastar. Ora, do seu lado, considerava que estava a desempenhar um trabalho positivo, que, no entanto, o levaria demasiado longe, ao defender os regimes fascista e nazi como resultantes da soberania popular, por isso, democráticos.

Ora, é difícil classificar esta tomada de posição de Faria e Maia como de "adesivismo" ao Estado Novo. É claro que nutria simpatia por Salazar enquanto "chefe" político

à política do Estado Novo em 1932-1933, in: Boletim do Instituto Histórico da Ilha Terceira, vol. XLIII (1990), Angra do Heroísmo, IHIT, 1993, pp. 507-536.

${ }^{48}$ A Gazeta, Ponta Delgada, 1932, Setembro, 28.

${ }^{49}$ Cf. Francisco d'Athayde M. de Faria e Maia, Em Prol da Descentralização. "Livre Administração dos Açores pelos açorianos”, Ponta Delgada, Jornal de Cultura, 1994 (1. a edição, 1932).

${ }^{50}$ Ibidem, p. 225. 
e que criticava fortemente os tempos agitados da I República. Teria, pois, uma expectativa benevolente sobre a evolução do regime. Será, pois, nesta medida que procurará distinguir a "essência" do Estado Novo - que, como vimos, não concebia como antiliberal - dos mais radicais propagandistas da nova situação.

Se aqui trazemos este caso individual é precisamente por esta tentativa de justificação pública, procurando conciliar duas ideologias opostas: a liberal e a antiliberal, antiparlamentar, nacionalista e corporativista.

Note-se, porém, que Faria e Maia não se compromete em aderir ao Estado Novo, sobretudo, à União Nacional. Respondendo ao desafio que Armando Cândido lhe lançou para abandonar e despir "a roupagem do século XVIII, a feia vestimenta do século XIX” e ingressar no Estado Novo, Faria e Maia é claro:

"Não! Esta transformação que S. Exa. de mim espera, e a que incita, não se dará. Não entrarei no Estado Novo por essa porta. Ficarei fora do Templo a auxiliar os celebrantes a ajudá-los em tudo o que me parecer justo, em tudo o que me parecer útil, em harmonia com o meu modo de ser [...]. Conservarei sempre a minha vestimenta antiga, que amo e que uso há longos anos, e com que já servi a Monarquia, exercendo um cargo público, sem que ela me impedisse de criticar abusos, desmandos e licenças dos partidos, com que já servi a República passada, sem ingressar nos bandos políticos" ${ }^{51}$.

Viria, de facto, a cumprir esta promessa, ao aceitar a presidência da Comissão Administrativa da Câmara Municipal de Ponta Delgada, entre 1940 e 1943, sem, contudo, aderir à União Nacional ou se arvorar em propagandista da "situaçãa". Terá sido este seu posicionamento perante o Estado Novo que o levou, em 1941, a oferecer os seus vencimentos como presidente da Câmara Municipal de Ponta Delgada a favor da verba votada para o "Balneário Municipal".

Quanto ao seu opositor, Armando Cândido de Medeiros, pouco há a dizer. Servira-se, ao refutar a interpretação liberal do Estado Novo, dos textos fundamentais, sobretudo dos discursos de Salazar. Armando Cândido era, aliás, o principal propagandista da nova situação, pelo menos em S. Miguel, pois tinha uma coluna semanal de doutrinação política, com principal relevo para a propaganda anticomunista, no quotidiano Correio dos Açores ${ }^{52}$.

$\mathrm{O}$ certo, como já se referiu, é que esta polémica não teve qualquer repercussão na imprensa açoriana. A crise económica e social, a Guerra Civil de Espanha, a política nacional e internacional, a propaganda do corporativismo, além de questôes de interesse local e sobre a literatura e cultura açorianas tomavam grande parte das páginas dos jornais.

\footnotetext{
${ }^{51}$ Francisco d'Athayde Machado de Faria e Maia,, Contenda..., pp. 13-14.

52 Além disso, publicou, por essa época, diversos opúsculos de doutrinação política, como, por exemplo, Corporativismo-comunismo: frente a frente, Ponta Delgada, Papelaria Âmbar, 1937, resultante do discurso que proferiu aos microfones do Posto Emissor CT2A J, na jornada anticomunista de 18 de Novembro de 1936; Porque sou legionário, Ponta Delgada, [s. n.], 1937; Não vivemos para cultivar o ódio, Praia da Vitória, Câmara Municipal da Praia da Vitória, 1940.
} 